\title{
Cases of a Borderline Pathology That Can Mimic Bladder Cancer: Primary Amyloidosis of Urinary Bladder
}

\section{Mesane Kanserini Taklit Edebilen Farklı Bir Patoloji: Mesanenin Primer Amiloidozu}

\author{
Cemal Selçuk İşoğlu, Hakan Türk, Mustafa Karabıçak, Orçun Çelik, Hüseyin Tarhan, Ferruh Zorlu
}

Tepecik Training and Research Hospital, Clinic of Urology, İmir, Turkey

\begin{abstract}
Amyloidosis is a disease characterised by accumulation of a fibrillar protein called amyloid in the extracellular space. The kidneys, ureters and the bladder can be affected in the urinary tract. However, primary amyloidosis of bladder is a rare entity. Macroscopic hematuria could be the first and only symptom of primary amyloidosis of the bladder; therefore, it has similar findings with urinary tract malignancies. Histopathological evaluation is mandatory for the diagnosis. Follow-up should always include cystoscopic evaluation as recurrence is expected in the natural course.
\end{abstract}

\section{Key Words}

Amyloidosis, macroscopic hematuria, bladder, cystoscopy

\section{ÖZET}

Amiloidoz, amiloid adı verilen fibriller proteinin ekstraselüler alanda birikimiyle karakterize bir hastalıktır. Üriner sistemde böbrekler, üreterler ve mesane etkilenebilir. Ancak mesanenin primer amiloidozu nadir bir durumdur. Makroskopik hematüri ilk ve tek semptom olabilir ve bu nedenle üriner sistemi ilgilendiren malignitelerle karışabilir. Histopatolojik değerlendirme tanı için olmazsa olmazdır. Doğal seyrinde tekrarlayabileceği bilindiğinden sistoskopik değerlendirme her zaman takibin bir parçası olmalıdır.

Anahtar Kelimeler

Amiloidozis, makroskopik hematüri, mesane, sistoskopi

\section{Introduction}

Amyloidosis consists of extracellular deposition of amyloid, in one or more body sites. In the urinary tract, amyloid accumulation is usually seen in renal pelvis, ureters, urinary bladder and even penis $(1,2,3,4)$. Primary amyloidosis localised in the bladder is a very rare entity which was first described by Solomin in 1987 (5). Both sexes are equally affected (5). Macroscopic haematuria can be a symptom and on cystoscopic evaluation, it can mimic a bladder tumor. In this report, we aimed to discuss two cases of primary bladder amyloidosis with diagnose and therapy.

\section{Case Reports}

\section{Case 1}

A61-year-old female patient admitted to the hospital with intermittent, painless, macroscopic haematuria. There was no specific finding on physical examination. In laboratory tests, the hemoglobin level was found to be $8.7 \mathrm{gr} / \mathrm{dl}$ and other parameters were within normal ranges. Complete urinalysis revealed $\mathrm{RBC}(+++)$. A view consistent with bladder haematoma was demonstrated by ultrasonography.

The filling defect was detected on right wall of the bladder which can be considered as bladder tumor by contrast-enhanced computed tomography (Figure 1). Fluffy and erythematous areas were visualised on the right wall of the bladder by cystoscopy. Samples were obtained with transurethral resection (TUR) from the right wall of the bladder. In the pathological evaluation of the samples, amyloid deposits that give apple-green birefringence with Congo red were detected in submucosa and vessel walls. Focal serum amyloid A (SAA) accumulation was detected in immunohistochemical studies (Figure 2). Hematology consultation was requested. Rectal biopsy, bone marrow biopsy and blood protein electrophoresis were performed and interpreted as normal. For possible recurrence risk, followup including cystoscopy controls were planned. No macroscopic mucosal pathology was detected in $3^{\text {th }}$ month cystoscopy.

\section{Correspondence}

Hakan Türk MD, Tepecik Training and Research Hospital, Clinic of Urology, İzmir, Turkey

E-mail: hkntrk000@hotmail.com Received: 02.03.2015 Accepted: 09.04.2015 


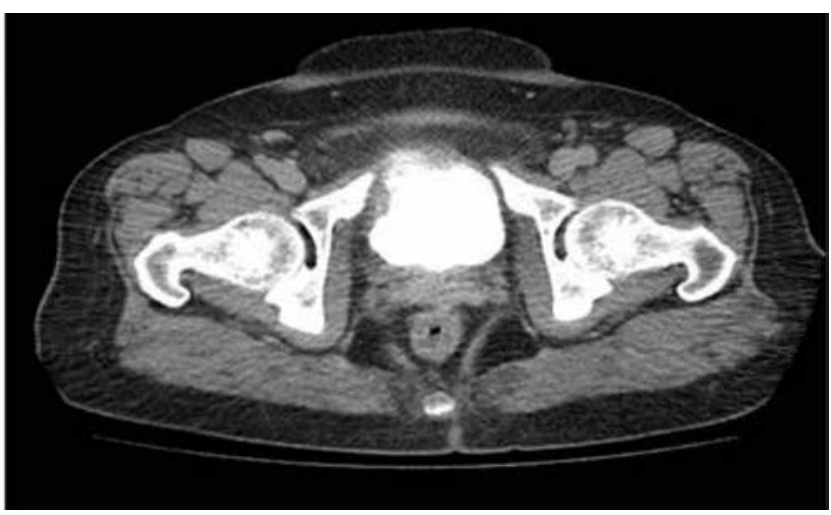

Figure 1. Urography with computered tomograpy, filling defect in right wall of bladder which can be considered as tumor

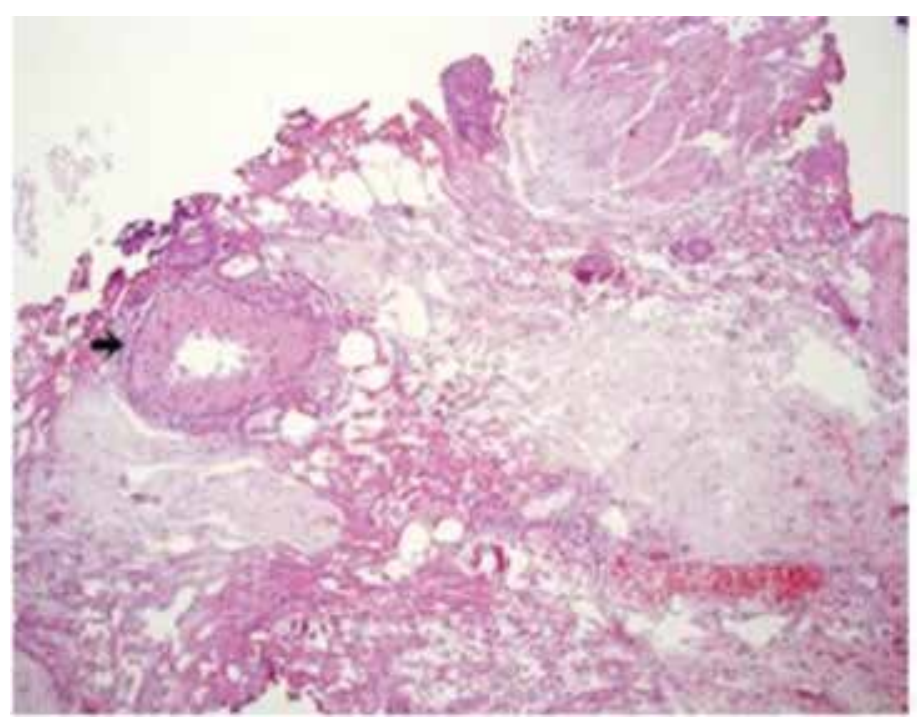

Figure 2. Focal amyloid accumulation

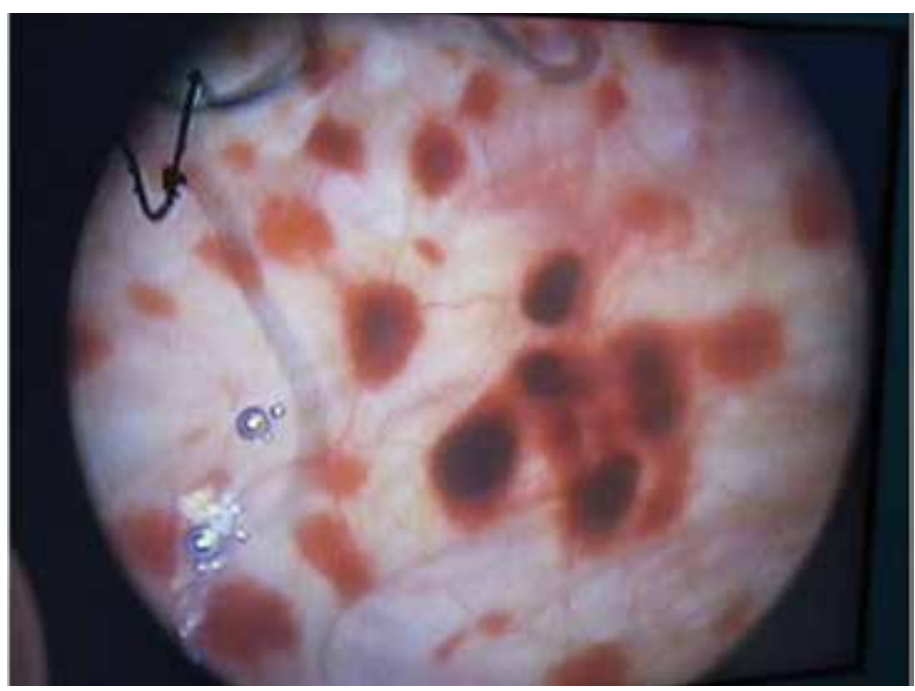

Figure 3. Cystoscopic view of amilodosis

\section{Case 2}

An 81-year-old male patient was admitted to our clinic with macroscopic haematuria. There was no specific family history. In 2008, TUR of the prostate was performed and $3+2=5$ adenocancer was detected with a PSA level of $5.6 \mathrm{ng} / \mathrm{ml}$. The patient was considered as having low-risk prostate cancer and being followed-up with watchfulwaiting protocol in our department. In laboratory tests, hemoglobin level was $9.7 \mathrm{gr} / \mathrm{dl}$ and serum creatinine level was $1.7 \mathrm{mg} / \mathrm{dl}$. Other parameters were within normal ranges. No space-occupying lesion was detected in the bladder by non-contrast computed tomography. Cystoscopy was performed for haematuria and erithematous lesions were visualised (Figure 3). TUR was performed. Amyloid accumulation that gives apple-green birefringence with Congo red was detected in subepithelial space around the vessels. With immunohistochemical studies, the accumulated material was diagnosed as serum amyloid A protein. For excluding systemic disease, hematology consultation was requested. Bone marrow biopsy was normal. Rectal biopsy was also performed and interpreted as normal. In the light of these information, this case was considered as primary amiloidosis of the bladder. For possible recurrence risk, cystoscopy controls were planned. Our patient is being followed up regularly for 2 years without any problem.

\section{Discussion}

Amyloidosis is a heterogeneous disease characterised by accumulation of amyloid protein in one single (localised) or multiple organs or tissues (systemic). It can affect any organ in the urinary tract, but primary localised bladder amyloidosis is uncommon with less than 90 reported cases $(1,2,4)$. In etiology, chronic cystitis and inflammation is blamed for accumulation of amyloid precursors in the bladder (6).

Bladder amyloidosis is generally seen in advanced ages and male/female ratio is equal $(5,7)$. Systemic amyloidosis is mostly asymptomatic, however, bladder involvement comes out with gross hematuria (60\%), irritative voiding symptoms (20\%), and both (20\%) $(1,2,8)$. Secondary bladder amyloidosis has been reported in 30 cases related to systemic diseases such as Crohn's disease, rheumatoid arthritis and ankylosing spondylitis.

Cystoscopic view can mimic a bladder tumor. Macroscopic features may be in different forms, such as yellow plaques, erythematous areas, solitary/multiple nodules, ulcerated polypoid mass or irregular thickness of the bladder wall $(1,2)$. In our cases, erythematous areas were visualused during cystoscopy.

In most cases, accumulation is limited with the urinary bladder but there are reports with ureter and urethra involvement (2). In our cases, the bladder was the only affected organ.

Up to the structure of the accumulated protein, the disease is called primary amyloidosis if the protein is $\mathrm{AL}$ (immunoglobulin light chain) and called secondary amyloidosis if the protein is SAA. In addition, there can be different protein deposits caused by several diseases.

Primary amyloidosis generally tends to accumulate in mucosa, secondary amyloidosis tends to accumulate in the vessel walls. Thus, this explains the haematuria that observed in secondary amyloidosis cases (8). In both cases, the patients were admitted with macroscopic haematuria and were diagnosed as having secondary amyloidosis due to SAA deposits and considered as primary localised amyloidosis of the bladder.

Histopathological evaluation is mandatory for diagnosis. Amyloid protein is congophilic and gives green birefringence in polarised 
microscopy (6). For differential diagnosis of primary and secondary amyloidosis, potassium permanganate test can be used. SAA protein vanishes after potassium permanganate administration. Differential diagnosis is important to find out the situation causing accumulation (5). Abdominal fat biopsy, rectal biopsy and bone marrow biopsy are recommended for screening (1). In our cases, rectal biopsy, bone marrow biopsy and serum protein electrophoresis were performed to find out if there was a systemic disease and no other amyloid accumulation and immunodyscrasia were detected.

TUR is the gold standard for the treatment of primary localised bladder amyloidosis. A recurrence rate of $50 \%$ has been reported in the field $(1,2,8,9)$. In $10 \%$ of patients, haematuria cannot be controlled with TUR, thus, partial or total cytstectomy can be an option in this situation (8). Our cases were treated well with TUR and followed up without problem.

Intravesical dimethyl sulfoxide, intravesical potassium permanganate or oral colchicine can be used as a bladder protection method of treatment but the benefits of these treatments are limited and controversial $(1,9)$.

Most of the authors suggests regular follow-up including cystoscopic evaluation. With cystoscopy, not only recurrence, but also the concomitant tumors can be detected (7).

\section{Conclusion}

Primary amiloidosis of the bladder is a rare entity which comes out with macroscopic haematuria. The disease can mimic bladder cancer, therefore, differential diagnosis is very important. Histopathological evaluation is mandatory. TUR or fulguration can be used as a conservative approach. Follow-up should always include cystoscopic evaluation as recurrence is expected in the natural course. In addition, malignancy risk always should be kept in mind due to the age intervals of patients.
Concept: Cemal Selçuk işoğlu

Design: Cemal Selçuk İ̧oğlu

Data Collection or Processing: Hakan Türk, Mustafa Karabıçak

Analysis or Interpretation: Cemal Selçuk İşoğlu, Hüseyin Tarhan, Ferruh Zorlu

Literature Search: Orçun Çelik, Hakan Türk

Writing: Cemal Selçuk işoğlu

Peer-review: Externally peer-reviewed.

Conflict of Interest: No conflict of interest was declared by the authors.

Financial Disclosure: The authors declared that this study has received no financial support

\section{References}

1. Malek RS, Wahner-Roedler DL, Gertz MA, Kyle RA. Primary localized amyloidosis of the bladder: experience with dimethyl sulfoxide therapy. J Urol 2002;168:1018-1020.

2. Biewend ML, Menke DM, Calamia KT. The spectrum of localized amyloidosis: a case series of 20 patients and review of the literature. Amyloid 2006;13:135-142.

3. Altwairgi A. Primary amyloidosis of the urinary bladder presenting as painless heamaturia. Int J Health Sci (Qassim) 2011;5:181-185.

4. Bayrak Ö, Bozdağ Z, Urgun G, Yağcı F. Primary amyloidosis of the bladder mimicking bladder tumor. Turkish Journal of Urology 2014;40:59-61.

5. Karan SC, Shah AK, Srivastava CA, Bhardwaj BR. Primary amyloidosis of urinary bladder: Mimicking transitional cell carcinoma bladder? Medical Journal Armed Forces India 2015;6:13.

6. Merlini G, Bellotti V. Molecular mechanisms of amyloidosis. N Engl J Med 2003;349:583-596.

7. Khan SM, Birch PJ, Bass PS, Williams JH, Theaker JM. Localized amyloidosis of the lower genitourinary tract: a clinicopathological and immunohistochemical study of nine cases. Histopathology 1992;21:143-147.

8. Tirzaman 0, Wahner-Roedler DL, Malek RS, Sebo TJ, Li CY, Kyle RA. Primary localized amyloidosis of the urinary bladder: a case series of 31 patients. Mayo Clin Proc 2000;75:1264-1268.

9. Wilkinson M, Fanning DM, Flood H. Primary bladder amyloidosis, BMJ Case Rep 2011;2011. 